\title{
Patron- Client Relation of Bajo Society in Local Leaders Election 2015: A Study in Marobo Village of Muna District
}

\author{
Bahtiar $^{1}$, Wa Ode Sifatu ${ }^{2}$ \\ 1. Halu Oleo University, Sociology Sociology Department, Social and Political Science Faculty. Indonesia. Home \\ Adress: BTN Kendari Permai Blok H2 Number 17, Kendari, Pos Code: 93232, Southeast Sulawesi, \\ Indonesia. \\ 2. Halu Oleo University; Anthropology Department of Cultural Science Faculty. Home Adress: BTN UNHALU \\ BLOK W, Number 28 Kendari, Pos Code: 93232, Sulawesi Tenggara, Indonesia.
}

\begin{abstract}
The focus of this article is to describe how the patron-client relation in Bajo society and what kind of patron power that affects Bajo society in local leader's general election. This research applies a case study method on Bajo society in Marobo Village during local leader's general election of Muna District 2015. The data technique is through observation and interview. The results show that Bajo society relation in Marobo Village is patron-client. The Bajo society has relations with formal leaders (head of village and headman / Bajo figures) as well as nonformal leaders(rich people) as their patrons. Bajo's political attitude is largely determined by patron's political attitude. The Bajo people in determining their political attitude is very considerate for long term benefit for their lives, not momentary interest. Bajo people's political attitude is not only achieved by relying on the power of money politics. The right choice of patrons will determine the election of candidate pairs in Bajo society. Patrons who have formal and informal structured relationships and intense relationships with Bajo society are more influential to patrons who merely depend kinship factor, violence and momentary.
\end{abstract}

\section{Keywords: The Relation of Patron-Client, Local Leader's General Election, Bajo, Marobo}

\section{Introduction}

This study was conducted to comprehend how patrons influence the Bajo society in local leader's election in Muna District. This study is important to do, because, the study of how patrons work in Bajo society, and its influence in the local leader's election is still limited. In various literature studies conducted in the sociological study, the study of patronage relations has been written by Burke, (2001), Putra (1988), Wolf (1983), Jackson (1981), Scott (1972) and Pelras (2009).

An important feature of this sociological study lies in how to understand patron-client relation as a social phenomenon based on inequality position between patrons and clients. This inequality position is in the context of control capacity over the resources of prosperity, in the form of goods and services. Therefore, this relation requires an awareness of their respective positions; Patron as guard / giver and client as loyalist. Thus, what the patron gives to the client and what the client presents to the patron becomes valuable because of the utilization basis of the exchanged resources.

If examined more deeply, patronage relations not only occur because of the relation between patrons and clients. There is a pre-condition typical as a field that grows patronage relations, that is, a deep social structure with a cultural-feudalistic value. This condition causes patronage relation not only the exchange of resources, but also the problem of socio-cultural conditions that are so feudalistic. Therefore, an in-depth study is needed to develop a patronage study integrated into cultural-feudalistic values; by analyzing the power relations formed in each social structure. Eventually, it is hoped to explain the nature of local patronage and comprehend why and how the main patron can have a strong political, social, cultural and economic influence. 
At the local leader's general election of Muna District 2015, the influence of patrons is crucial in the local leader's election. This is seen on the Bajo people's political choices during the re-voting at Voting Place 1 of Marobo Village which is won by one of the local leader candidates due to Bajo people's support. The political choice of the Bajo people in Marobo Village is deeply affected by their patrons who are highly respected and affirmed by the Bajo people. The intended Patron is the head of the village and the resident (the wealthy / owner of the estate / economic ruler).

The head of Marobo Village by Bajo people are very respectable, as they take control of the leadership from the village level to the headman. The head of the village also determines the distribution of government social assistance that is needed by the Bajo people. The position and authority possessed by the head of the village made him highly respected among the Bajo people, although they differed ethnically.

Bajo people's political attitude at Voting Place 1 of Marobo Village is also strongly influenced by the presence of 'wealthy people' who are in control of the economic resources among Bajo people. 'The wealthy people' referred to is a society leader who has wealth of owned business include the field of transportation, moneylenders, fish container handlers, livestock owners and distributors of drinking water which is needed by Bajo people. The support of 'wealthy people' to one of the local leader candidates seems to be in line with Bajo people's political choices. Bajo people's political attitude does not flow away, but is strongly influenced by the role of patrons who intensely approach the electorate especially in the run-up to the Election Day. Based on the above phenomenon, this paper tries to answer the question how is the patron-client relation on Bajo society in the local leader's election? What is the power and role of patrons in influencing society?

\section{Theoretical Basis}

The patron-client relation is understood as patronage that is a concept of power born out of an imbalanced relation between patrons on the one hand and clients on the other. This imbalance is basically closely related to the unequal ownership of resources in society. In sum, the practice of patronage is built on from differences in economic conditions as well as differences in the capacity of controlling resources resulting in an interdependence relation; patrons need clients to help patrons keep their resources. While clients are need protection and welfare from patrons. Hence, in such phenomena the interrelation has been tied up by interest and manipulated by its own purposes although both are in an unbalanced position. In this context Scott (1972: 92) argues that:

The patron-client relationship - an exchange relationship between roles-may be defined as a special case of dyadic (two person) ties involving a large instumental friendship in which an individual of higher socioeconomic status (patron) uses his own influence and resources to provide protection or benefits, or both, for a person of lower status (client) who, for his part, reciprocates by offering general support and assistance, including personal services, to the patron.

Scott mentions that a patron has a higher social and economic power that uses the influence and sources of his or her life's need to provide protection and benefit to others (clients) who respond by providing support and assistance including personal service to the patron. Furthermore, the patron-client group may form a patron relation with multiple clients (patron client cluster) or it could be a combination of several patronclient groups led by a patron as the highest patron called patron client pyramid (Maswadi Rauf, 2001).

Meanwhile, Lande (1977: xx) defines this patron client relation as follows:

A patron client relationship is a vertical dyadic, i.e, an alliance between two person of unequal status, power or resources each of whom finds it useful to have as anally someone superior member of such an alliance is called a patron. The inferior member is called his client.

Referring to the above description, patron-client manifests because of unequal relationships but needs each other. On the one hand, patrons appear as individuals who have advantages both in terms of wealth, status and influence. On the other hand, the client is present as a member of society who does not have the resources owned by patrons'.

The basic assumption of this conceptual framework lays a way of thinking that insists that relations will occur if both parties get benefit from the relations they intertwine. At least the mechanism is like this: the patron group provides economic assistance and 
protection to the client group or its subordinates; and in return for the giving, the client class gives their devotion and allegiance to the patron. One characteristic of patron-clients is the unique exchange of resources through the practice of integrating patronage into cultural and political settings in the society in which the practice takes place. This condition explains that patron-client is locked by a value system as a certain ethical-moral order. Therefore, relations in this context can be interpreted as a relation based on the exchange of interests.

In the sociology study the exchange pattern is closely related to the daily life of human described in the theory of social exchange. Blau (1964: 88-89) one of the sociologist figures mentioned that social exchange is the exchange in which greatly influenced by the individuals value system and the value system of their social environment. Blau further mentioned that social exchange takes place in the form of gift and services exchange. The received gift is not voluntary, but is given under obligation. Furthermore, something that exchanged is not only in the form of goods and wealth, real and personal property and economic value, but also courtesy, entertainment and others. Although the patron-client relation is based on the value of interest exchange, but the exchange remains unbalanced. This is due to the direct control over the main resources within the society or state.

\section{Research Method}

This research was conducted in Marobo Village, Marobo Sub-district, Muna District. The time of the study started from March to April 2016. This research type is a descriptive qualitative that aims to reveal the influence of a certain condition, facts, phenomena, the circumstances that occur when the study conducted and show as it is. This research was conducted using case study method. The subjects in this study are Bajo society. Bajo people are selected because they are the most voters listed in the list of permanent voters (LPV). From 660 LPV, about $60 \%$ are Bajo people. Of that amount, interviews were only conducted on some people who were considered understand and were involved directly or indirectly in the election process

Data collection techniques are (1) interviews, this data collection is by asking directly to the subject who knows the problem. Interviews are intended to obtain in-depth information about the patron-client relation and the role of patrons in the local leader's general election. (2) Observation, this is done to observe the activities undertaken by the Bajo people before the voting takes place. Results of data processing then analyzed using data reduction techniques, data presentation, and conclusions.

\section{Result and Discusion}

\subsection{The Social Life of Marobo Village}

Marobo is one of the villages in Marobo Subdistrict of Muna District, Southeast Sulawesi. Marobo village is located in the southern part of Muna District which is bordered directly to Central Buton District. Marobo Village territory is bordered to the Spelman Strait in the west, Wadolau Village in the north, Pearoha Village in the east and Central Buton District on the south. Geographical condition of Marobo Village is located in coastal area which covered by swamp, mangrove forest and cashew nut farm.

Marobo village can be accessed by landline and sea lane. The landline can be reached through the district road connecting Marobo sub-district and the surrounding sub-district. The mileage of Marobo Village with the capital of Muna District reached $83 \mathrm{~km}$. The landline to Marobo can also be accessed through the Central Buton District which is about $20 \mathrm{~km}$ away. Furthermore, the sea lane can be reached through the Central Buton District and Wasolangka Village, Parigi sub-district Muna District. Marobo village consists of four hamlets namely Kowa-Kowa, Boru, Marobo and Bajo (beach).

The residents of Marobo Village consists of three ethnic groups namely Muna, Buton and Bajo. Muna is a native of Muna District, while Buton is an outsider tribe. The existence of the Buton people in Marobo because this area is bordered directly by the Central Buton District. While Bajo is one of the tribes that live in the sea, the edge of the sea (coastal) and among the cluster of islands. For Bajo people, sea is the source (panamamie ma di lao). The Bajo people have principle of 'pinde kulitang kadare, bone pinde same kadare', which means moving Bajo people to land same as moving turtles to land (Suyuti, 2011). The Bajau (Bajo) are found in the waters of the Makassar Strait, Bone Bay, in East Nusa Tenggara, Banggai Islands in eastern Sulawesi, North Maluku in Bacan and Halmahera Islands, in the marine waters of Sulawesi and Sulu Islands (Lapian, 2011). The Bajo people live freely (nomadic) looking for a place that is considered safe to ensure their survival.

In Marobo village, Muna people occupy the 
eastern region (Marobo hamlet) with geographical characteristics of rocks. Buton people inhabit the northern region (Boru and Kowa-Kowa hamlet) with red soil characteristics. While the Bajo people are occupy the coastal area located on the west (Bajo hamlet). The location of the residents' residence of Marobo Village is related to their profession as farmers and fishermen. Muna people who mostly work as farmers settled in the eastern part, because the area is available for agricultural land and farms. While the Buton people who work as seaweed farmers, living in the northern region bordered to the beach. Another case of Bajo people who are settled in the coastal area because it is bordered to their daily workplace as a fisherman.

Although inhabited by three ethnic groups, the social relation of Marobo society is very harmonious. Muna people desperately need Bajo people as well as vice versa. The intimacy of different ethnic groups of people is seen when in the fulfillment of their daily needs. Muna people who work as farmers and providers of basic commodities / groceries (traders) need fish caught by the Bajo people. Similarly, Bajo people need basic food provided by Muna people. The interaction is so frequent between the Muna and Bajo people that they master two languages at once, so that at first glance can not be distinguished between the Muna and Bajo people. Peribadi (2000: 85) mentions the life characteristics of Bajo tribe community that are: (1) occupies an archipelago surrounded by the sea; (2) fishing is a livelihood carried out from generation to generation; and (3) have the same language dialect.

The social structure of fisherman communities is generally characterized by strong patron-client bonds. The relationship between the Muna and the Bajo people in Marobo Village is generally occur relationally. However, these relationships gradually became subordinated due to the low level of education and lack of entrepreneurial spirit among the Bajo society. The low level of education and the weakness of the Bajo people's economy make them very dependent on those who have knowledge and possess wealth. The educated and wealthy Marobo people are from the Muna ethnic. While many Bajo people do not continue their education.

The educators, traders and government apparatus profession are held by the Muna people. The highest position headed by the Bajo people is only the village chief, and even then only limited to the environment they live. The position of the village chief is not free; they are very dependent to the head of the village who determines the distribution of government social assistance-such as cows, rice for poor and boats-which is very much expected by the Bajo people. Bajo people are also very dependent to local entrepreneurs who are collecting fish crops, providers of drinking water (gallons) and loan sharks. The head of the village and rich people in Marobo are from the Muna ethnic. This makes the Bajo people subordinated.

\subsection{Local Leader's General Election and the Importance of Bajo People}

The electoral impact of the Bajo people in the local leader's general election of Muna is very small; this is because the Bajo society in Muna is only a small part of the population of Muna. Bajo people generally occupy coastal areas. In Muna, Bajo people occupy coastal areas. They are commonly found in Marobo, Tapi-Tapi, Kawite-Wite, Latawe, Lagasa, Kambara (Bahtiar, 2010). The village is a coastal area. Besides inhabiting the coast, the Bajo people in Muna also inhabit small islands such as Balu Island (Nasruddin, 2011) and Bangko Island (Wikra, 2014). Another characteristic of Bajo people is their sedentary lifestyle, so they have no fixed residence.

The insignificant number of Bajo people in Muna district makes them unfavorable. In the era of direct Pemilukada, politicians need the electoral support of the majority group. This situation is further complicated by the absence of a clear address because it is often moved around. This implies the inaccurate accuracy of the number of Bajo people who already have the right to vote or not. In this condition makes the Bajo people unimportant to the politicians who fought. Even though there are politicians who try to approaches the Bajo people, these politicians aren't expecting to win or be elected by the Bajo people.

According to politicians, Bajo people are very agile to deceive them. A politician told of his experience when he looking for gain support from the Bajo community. When the politicians visit their villages, the Bajos flatter and convince the politicians that in their village all voters will elect the politician, even if the fish can vote, the fish will choose the politician. The flattery made politicians very confident that the Bajo people were one of bases his voice. In order to maintain that support, the politician gives money and stuff (clothes) to Bajo people. Nevertheless, the politician's expectations different when the election is over, the politician don't 
get a significant voice from the Bajo community. Since the event was be constructed stereotype among politicians and people in Muna District, that Bajo people difficult to keep his promise, so not to be expected as a supporter masses. Moreover, their community very small, so the voice of Bajo people is not too calculated.

This situation is became different when the Muna District Election of 2015, the Bajo were unimportant became very important. It begins from decision of the Constitutional Court (MK) to order the Regency KPU Muna to conduct re-voting (PSU) in 3 TPS. One of three polling stations is TPS 1 of Marobo Village, Marobo District, where the majority of the Bajo people. The result of observation indicate that 660 voters as listed permanent voters list (Election Commission of Muna, 2015) as much as $60 \%$ are Bajo people. The very dominant percentage of Bajo people became interesting votes of candidates for Regent and Vice Regent to win Muna election.

Of three candidate pairs, the competition at TPS 1 Marobo only involves two candidate pairs namely candidate pair number one and number three, this because the difference votes of both. In order to win the election, the candidate pair number one and number three actively approach the voters, especially the Bajo people as the majority voters in the DPT. In contrast to the couple's number two more relaxed and receptive the lose, this is because their votes are too small and have no chance of winning the Muna Regency Election. Meanwhile, the pair number one and three still have the same chance to win Pemilukada Muna Regency, if the re-voting won by one of them.

Tabel. 1. Candidate Regent and Vice Regent Muna 2015

\begin{tabular}{|c|c|c|c|c|c|}
\hline No & $\begin{array}{c}\text { Pairs } \\
\text { Candidate }\end{array}$ & Party & Etnic & Background is & $\begin{array}{l}\text { based on the consideration of still having a strong } \\
\text { mmunity, even though he is no longer in office. }\end{array}$ \\
\hline 1 & $\begin{array}{l}\text { L.M. } \\
\text { Rusman } \\
\text { Emba-Malik } \\
\text { Ditu }\end{array}$ & $\begin{array}{l}\text { PDI.P and } \\
\text { Demokrat }\end{array}$ & $\begin{array}{l}\text { Muna/ } \\
\text { Muna }\end{array}$ & $\begin{array}{l}\text { Member } \\
\text { DPD/Vice Regentn } \\
\text { Muna Petahana ut }\end{array}$ & $\begin{array}{l}\text { Not different from the number one pair, the pair } \\
\text { mber three who also the Regent of the petahana } \\
\text { thize the personage of village head and principal to } \\
\text { tract electoral support. }\end{array}$ \\
\hline 2 & $\begin{array}{l}\text { Laode } \\
\text { Arwaha- } \\
\text { Laode } \\
\text { Samuna } \\
\end{array}$ & $\begin{array}{l}\text { PKB and } \\
\text { HANURA }\end{array}$ & $\begin{array}{l}\text { Muna/ } \\
\text { Muna }\end{array}$ & $\begin{array}{c}\text { Member of } \\
\text { Province DPRD } \\
\text { /Member of } \\
\text { Regency DPRD } \\
\end{array}$ & $\begin{array}{l}\text { The doctor using (pair number three) village } \\
\text { leader and Ando Hadis (headmaster of SDN } \\
\text { and local businessman, informan K. in Marobo, } \\
\text { 2016) }\end{array}$ \\
\hline 3 & $\begin{array}{l}\text { L.M. } \\
\text { Baharuddin- } \\
\text { La Pili }\end{array}$ & $\begin{array}{l}\text { PAN, Golkar, } \\
\text { PKS, } \\
\text { GERINDRA, } \\
\text { NASDEM }\end{array}$ & $\begin{array}{l}\text { Muna/ } \\
\text { Muna }\end{array}$ & $\begin{array}{l}\text { Regent } \\
\text { Petahana/Member } \\
\text { of Province DPRD' }\end{array}$ & $\begin{array}{l}\text { In the rule of law the position of village head } \\
\text { nd principal must be neutral and not allowed become a } \\
\text { accessful team. However, in the elections in Marobo }\end{array}$ \\
\hline
\end{tabular}
pair number one took advantage of the former village chief and the village gang leader as quoted in the following interview:

The first candidate use with "hardware" (thugs) in their strategy and the former village leader who still have influence. From this thugs we are given money. While the former village leader he walked by visiting his family in the village of Bajo (Informan R, in Marobo, 2016).

Using thugs in the election for avoiding the attention of monitors or reports from other candidates' successful teams. For those who report the behavior of thugs, their lives will be shadowed with threats. Furthermore, the election of the former leader of village is based on the consideration of still having a strong Not different from the number one pair, the pair 
Village (Muna Regency in general) the government apparatus was actively involved as the winning team of the candidate pair. In order to avoid organizers' monitoring and avoidance of government regulatory sanctions the government apparatus positioned itself as a covert successful team. Village Head Marobo and Ando Hadis is a covert successful team in pair number three. The village head and Ando Hadis are Marobo villagers with Muna ethnicity.

Using the village leader of Marobo as a covert team of pair third candidate because their relationship the Village Leader and LM Baharudin were as leader and officers in bureaucracy. Before appointed as a candidate for Regent, L.M. Baharudin is the regent of petahana, as well as the superior of the village leader. During the leadership, Regent L. M Baharudin give trust and a strategic role to the village head as a formal government leader. As the highest leader in the village, the village head plays a role in determining the distribution of government social aid and village development projects.

The joining of Ando Hadith in the covert successful team of the pair third candidate, in addition based on the relationship of leader (Regent) and officer in bureaucracy (Principal Elementary School), has its own reasons. Ando Hadis is known as a prominent public figure and ruler of economic resources in Marobo village. In Marobo Ando Hadis is the owner of milkfish, transportation and public transport (car and motorcycle), cattle owners and drinking water seller (gallon). In the 2010 General Election (before 2015), Ando Hadis is a supporter of L.M. Rusman Emba (candidate for Regent). The allegation of Ando Hadith to L.M Rusman Emba at that time wasn't separated from the direction of regent Petahana Ridwan Bae (Chairman of DPD Golkar Sultra) who supporting L.M Rusman Emba (Golkar Party cadres). At (2010) Ando Hadis served as head of elementary school in Marobo. LM Rusman Emba's defeat in general election 2010 made Ando Hadis knocked out as head of school. L. Baharudin who was elected as the regent of non-job of Ando Hadis as head of school. The loss of the principal's position did weaken the influence of Ando Hadith in Marobo, as the economic ruler (especially the Bajo people) he remained influential. The influence and character of Ando Hadith made him embraced by L.M Baharudin by being reappointed as the head of elementary school.

The other side the duties as head of school, Ando Hadis from the village government is believed to handle of the government's fish storage. Bajo catch fish are sold in fish shelters controlled by Ando Hadis. The sector of business that was cultivated by Ando Hadith also made him often meet people Bajo. Number of businesses owned by Ando Hadis supply Bajo people's basic needs, such as food and drinking water. The need for drinking water and clean water is needed by Bajo people who live on the coast as impact of the absence of a natural source of clean water (river) or provided by the government. Even if the government distributes water to the people of Marobo through PDAM pipes, this doesn't touch Bajo village on the coast and on the sea (floating house).

The character and good relationship of Ando Hadith with the village government has made him also influential in determining proper or inappropriate communities to receive village aid, such as poor rice and livestock (cattle). The efforts and roles run by Ando have a direct relationship with the Bajo people, especially the village chiefs. Ando Hadis often lend the motor to the figure of Bajo (head-of-village).

In emergency situations Ando Hadith also become of Bajo people's hopes when they need financial aid (lend). The transportation public (transportation) also owned by Ando Hadis whom serving the needs of Bajo who want to travel outside the subdistrict (kecamatan). Bajo hanging on land transportation, this is because there is no transportation that they have except the boat. Bajo people are very good at steering boats when big waves though, but they do not have skills to drive land transportation such as motorcycles and cars. The Bajo life on the coast, make the boat become their primer transportation. From this habit led to jokes among people outside Bajo, that Bajo people get drunk on the land rather than sea. The point of the phrase is that Bajo people while using sea transportation never get drunk, but they are drunk while using land transportation. According to Mamar Sulaeman (2005: 2) Sea and Bajo people are two things that cann't be separated in Bajo culture. Therefore, there are two main concepts put forward namely: (1) Sea, is a vast territorial waters and salty water that has various functions. Sea for Bajo people is absolute, because in addition as a residence, as well as a place to earn a living, (2) Bajo people, is a group of sea nomads who live with their families in the sea or coast.

Person unaccustomed Bajo and beggary as Bajo's person cause have no bicycle wheels two and wheeled empatl. On the contrary, resource mastery 
social and economic available on Ando Hadis, in consequence it really being obeyed among Bajo's society. Person unaccustomed Bajo and beggary as Bajo's person cause have no bicycle and car. On the contrary, resource mastery social and economic available on Ando Hadis, in consequence it really being obeyed among Bajo's society.

Ando Hadis as person that really been honoured and obeyed by their oldster (person Bajo). Since our oldster droops same him, therefore us its children droop same her, what say so by her we follow. Upon Pilkada yesterday, there are many person Bajo chooses number three since Ando Hadis's roles ( informan F. in Marobo, 2016).

In addition to habit and inadequacy, poverty is also the cause of Bajo people do not have the equipment of land transportation. Conversely, the mastery of social and economic resources is on Ando Hadith, therefore he is strongly obeyed among the Bajo people.

He (Ando Hadith) is very respected and obeyed by our parents (Bajo people). Because our parents are obeyed to him, so we as they children also obeyed to him, what he said we follow. At the time of the elections yesterday, many Bajo people voted third candidate because of the role of Ando Hadith (informan S. in Marobo, 2017)

The influence of Ando Hadith is recognized by the team's successful number one partner, L.M. Rusman Emba, as quoted in the following interview quotes:

Ando Hadith is very influential there, he is a businessman. Ahead of the PSU, he was contacted by Mr. Ridwan (member of the House of Representatives / Former Regent of Muna) in support of Mr. Rusman but he reasoned that he had already supported the doctor (informan H. in Marobo, 2017).

Economic ownership makes Ando Hadis very influential. The allegations of Ando Hadith were able to change the political constellation in Marobo. Therefore, even though the regime has changed Ando Hadis it is still necessary to maintain support for every election.

When the election, patrons in the Marobo intensely establish communication and visits in villages of
Bajo. The first Candidate pair seeks to influence Bajo people through thugs and former village leader. The thugs acts as a holder and a money-shareholder. Thugs are also became a pressuring tools of the Bajo people who are seen in favor of the pair third candidate. Meanwhile, the former village leader ahead of the election diligently visiting his family in the village of Bajo. Despite having a family in the Bajo, the former the village leader wasn't able to embrace more Bajo people. This is because the former village leader isn't a Bajo figure. The Bajo people will follow who is their leader etreemly, like the village leader. These Bajo figures have established intense communication with the village leader and thet are hanging on the social and economic resources owned by Ando Hadis.

In contrast, the third candidate using the village leader and Ando Hadith to influence the Bajo People. In order to win the third candidate, village leader and Ando Hadis establish intense communication. The way in which the Village leader and Ando Hadith is more structured. The Village leader and Ando Hadith fortify the third candidate with political, social and economic power. Bajo figures (village leader) are under their control. When Bajo people supports other candidate outside Bajo leader's direction, they will be ostracized and against their parents. Ando Hadis meeting with Bajo's people is very intense. Every time Ando Hadith becomes a supplier of basic needs of citizens. This gap is exploited by Ando Hadith to convince the Bajo to choose the third candidate. The result of the election in Marobo was won by the third candidate (L.M. Baharuddin-La Pili) with 237 votes, while the first candidate (L.M. Rusman Emba-Malik Ditu) only received 156 votes (KPU Muna, 2016). Difference of third candidate to first canidate is 81 votes. The result is inseparable from the support of Bajo patrons in the village of Marobo village leader and Ando Hadis (rich people). Despite winning at Marobo, the number of votes earned by the third candidate seemed insignificant, because overall the vote counting of Muna Election was won by the first candidate. Nevertheless, these findings have important significance about the strength and role of patrons in Bajo society.

\section{Conclusion}

Money politics, mobilization of voters and the role of patrons is a strategy pursued by politicians in an effort to improve electability in general election (Pemilukada). Nevertheless the money factor and mobilization of the electorate seem ineffective if it isn't 
sustained by a more powerful and influential patron position. Selection / using of patrons will be determine the elected of candidates. Patrons that have formal and informal structured relationships and intense relationships with the community are more obedient than patrons who only family closeness and violence. Bajo people who have patronage relationships with formal leaders (village leader) and economic rulers (Ando Hadis) are more long-term and provide many benefits. While the thugs and the former to the village are only short-lived through money politics. This illustrates that the Bajo people in determining their political attitudes deeply consider the long-term benefits to their lives, not for a moment. The votes of the Bajo people can't be bought easily. These findings as a warning to politicians not to rely on money politics in elections.

\section{Acknowledgements}

We would like to thank Research's directorate and Society Devotion, Research's Ministry, Technology, and Higher Education Republic of Indonesia for motivating and support through this rsearch. Our Halu oleo University, notably Observational Institute and Devotion to Society. All our colleagues in Halu oleo University, all societies at Marobo, specially Ando Hadis have been instrumental in the preparation, research in Marobo Village. This work is dedicated to La Ode Rusman Emba as the Muna's regent and his indelible work supporting all stakeholders.

\section{References}

[1] Bahtiar. 2011. Transisi Kebudayaan Suku Bajo. HISPISI Cabang Sultra: Kendari.

[2] Burke, Peter. 2001, Sejarah dan Teori Sosial, Jakarta: Yayasan Obor Indonesia.

[3] Peribadi. 2000. Kedudukan dan Peranan Perempuan Dalam Sistem Kekerabatan Masyarakat Bajo. Tesis Pasca Sarjana. Bogor: IPB.

[4] Putra, Heddy Shri Ahimsa. 1988, Minawang, Hubungan Patron-Client di Sulawesi Selatan, Yogyakarta: Gadjah Mada University Press.

[5] Wolf, Erick R. 1983, Petani, Suatu Tinjauan Antropologis, Jakarta: CV. Rajawali.

[6] Jackson, Karl D. 1981, Urbanisasi dan Pertumbuhan Hubungan Patron-Klien: Perubahan Kualitas Komunikasi Interpersonal di Sekitar Bandung dan Desa-Desa di Jawa
Barat, Jakarta: Fakultas Ilmu-Ilmu Sosial Universitas Indonesia.

[7] Lande, C.H. 1977. Introduction: The Dyadic Basic of Clientalism. Dlm. Steffen W. Schmidt \& James C. Scott (eds.). Friends, followers and factions a reader in political clientalism, xiiixxxvii. Berkeley: University of California Press.

[8] Lapian, Adrian.B. 2011. Orang Laut, Bajak Laut, Raja Laut: Sejarah Kawasan Laut Sulawesi Abad XIX. Komunitas Bambu: Jakarta.

[9] Rauf, Maswadi. 2001. Konsensus Dan Konflik Politik. Sebuah Penjajagan Teoritis. DIKTI: Jakarta.

[10] Sulaeman, Mamar. 2005. Kebudayaan Masyarakat Maritim. Palu: Tadulako University Press.

[11] Suyuti, Nasruddin. 2011. Orang Bajo di Tengah Perubahan. Ombak: Yogyakarta.

[12] Scott, James C. 1972, 'Patron-Client Politics and Political Change in Southeast Asia', dalam Friends, Followers, and Factions A Reader in Political Clientalism, Steffen W. Schmidt (Ed.), Berkeley: University of California Press.

[13] Pelras, Christian. 2009. 'Hubungan Patron Klien pada Masyarakat Bugis dan Makassar di Sulawesi Selatan' dalam Kuasa dan Usaha di Masyarakat Sulawesi Selatan, Roger Tol dkk (Ed.), Makassar-Jakarta: Ininnawa-KITLV Jakarta.

[14] Blau, Michael Peter. 1964. Exchange in Power in Social Life, New York: Wiley and Sons, 1964. HIm. 88-89.

\section{Informants:}

[1] R., Bajo ethnic, Interviwed in Marobo Village .

[2] K., Bajo ethnic, Interviwed in Marobo Village

[3] F., Muna ethnic, Interviwed in Marobo Village

[4] S., Muna ethnic, Interviwed in Marobo Village

[5] H., Candidate Head of Tim by L.M Rusman Emba couple as winner. 


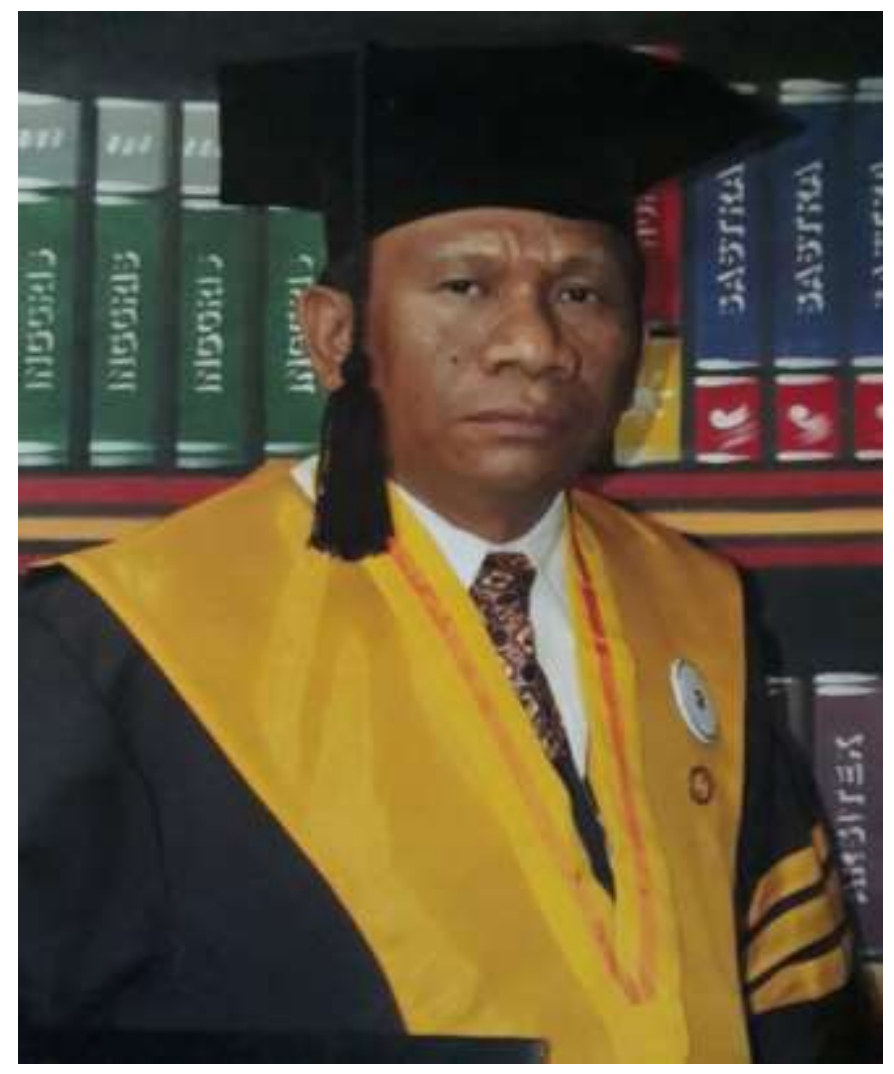

Bahtiar received the Halu Oleo University, Kendari, Indonesia in Sociology degree in 19841990; post graduate from Pajajaran University in 1996 - 1999 in Bandung; and doctoral degree from Pajajaran University in Bandung in 2001-2008. During 2008-2012 head of Development Administration Post graduate at Halu Oleo University. During 2012 - 2014 ftce rektor to Student and alumni program. During 2014 until now Dean of Social and Political Science Facultu, Halu Oleo University. . 